\title{
Treatment with docetaxel in combination with Aneustat leads to potent inhibition of metastasis in a patient-derived xenograft model of advanced prostate cancer
}

\author{
Sifeng $\mathrm{Qu}^{1,2,3}$, Xinpei $\mathrm{Ci}^{1,2,4}$, Hui Xue ${ }^{1}$, Xin Dong ${ }^{1}$, Jun Hao ${ }^{1,2,3}$, Dong Lin ${ }^{1,2}$, Pier-Luc Clermont ${ }^{5}$, Rebecca Wu ${ }^{1}$, \\ Colin C Collins ${ }^{2,4}$, Peter W Gout ${ }^{1}$ and Yuzhuo Wang ${ }^{\star, 1,2,3,4}$ \\ ${ }^{1}$ Department of Experimental Therapeutics, BC Cancer Agency, Vancouver, BC V5Z 1 L3 Canada; ${ }^{2}$ Vancouver Prostate Centre, \\ Vancouver, BC V6H 3Z6, Canada; ${ }^{3}$ Interdisciplinary Oncology Program, Faculty of Medicine, University of British Columbia, \\ Vancouver, BC V5Z 4S6, Canada; ${ }^{4}$ Department of Urologic Sciences, Faculty of Medicine, University of British Columbia, \\ Vancouver, BC V5Z 1M9, Canada and ${ }^{5}$ Faculty of Medicine, Université Laval, Québec, QC G1V OA6, Canada
}

Background: Docetaxel used for first-line treatment of advanced prostate cancer (PCa) is only marginally effective. We previously showed, using the LTL-313H subrenal capsule patient-derived metastatic PCa xenograft model, that docetaxel combined with Aneustat (OMN54), a multivalent plant-derived therapeutic, led to marked synergistic tumour growth inhibition. Here, we investigated the effect of docetaxel + Aneustat on metastasis.

Methods: C4-2 cells were incubated with docetaxel, Aneustat and docetaxel + Aneustat to assess effects on cell migration. The LTL-313H model, similarly treated, was analysed for effects on lung micro-metastasis and kidney invasion. The LTL-313H gene expression profile was compared with profiles of PCa patients (obtained from Oncomine) and subjected to IPA to determine involvement of cancer driver genes.

Results: Docetaxel + Aneustat markedly inhibited C4-2 cell migration and LTL-313H lung micro-metastasis/kidney invasion. Oncomine analysis indicated that treatment with docetaxel + Aneustat was associated with improved patient outcome. The drug combination markedly downregulated expression of cancer driver genes such as FOXM1 (and FOXM1-target genes). FOXM1 overexpression reduced the anti-metastatic activity of docetaxel + Aneustat.

Conclusions: Docetaxel + Aneustat can inhibit PCa tissue invasion and metastasis. This activity appears to be based on reduced expression of cancer driver genes such as FOXM1. Use of docetaxel + Aneustat may provide a new, more effective regimen for therapy of metastatic PCa.

Prostate cancer is the most common, non-cutaneous malignancy in North American men and a major cause of cancer deaths (Attard et al, 2016). At the time of prostate cancer diagnosis, the 5-year survival rate of patients with localised disease is almost $100 \%$; in contrast, the 5-year survival rate of patients with metastatic prostate cancer is much lower, about 28\% (Zustovich and Pastorelli, 2016). Metastasis is the most lethal attribute of cancer
(Chaffer and Weinberg, 2011) and is based on complex, successive biological steps of primary cancer cells, that is, local tissue invasion, intravasation, survival in the circulation, extravasation and metastatic colonisation, all essential steps in the metastatic process (Valastyan and Weinberg, 2011).

Metastatic prostate cancer is at present an incurable disease. For its treatment, there are only a few drugs available with, however,

*Correspondence: Dr Y Wang; E-mail: ywang@bccrc.ca 
limited efficacy. Docetaxel-based chemotherapy was approved in 2004 as a first-line treatment for metastatic, castration-resistant prostate cancer (mCRPC), even though it only marginally improved patient survival (Tannock et al, 2004; McKeage, 2012). In the case of metastatic, but androgen-sensitive prostate cancer, Phase-III clinical trials demonstrated that treatment with docetaxel-based chemotherapy plus androgen deprivation therapy (ADT) could improve patient survival and failure-free survival (time from randomisation to biochemical or clinical, disease progression or death) compared to use of ADT alone (RamosEsquivel et al, 2016; Tucci et al, 2016; Vale et al, 2016). Furthermore, docetaxel-based chemotherapy plus ADT was shown to improve failure-free survival of patients exhibiting nonmetastatic, androgen-sensitive prostate cancer (Vale et al, 2016). However, the toxicity of this new regimen is of major concern (Gravis et al, 2016; Tucci et al, 2016). Other pharmaceuticals such as Zoledronic acid, Denosumab and Radium-223 have severe limitations, restricting their use for prostate cancer treatment (Smith et al, 2012; Lewis et al, 2015; Wirth et al, 2015).

Numerous clinical trials have focused on improving the efficacy of docetaxel in treating mCRPC by combining it, as a pivot drug, with a variety of other anticancer agents, including tyrosine kinase inhibitors (e.g., Dasatinib (Araujo et al, 2013)), anti-angiogenic agents (e.g., Bevacizumab (Kelly et al, 2012)), bone-targeted agents (e.g., Zoledronic acid (James et al, 2016)) and experimental drugs (e.g., Atrasentan (Quinn et al, 2013)). However, Phase-III clinical trials of such docetaxel-based combinations have so far failed to demonstrate improvements in overall survival of mCRPC patients (Galsky and Vogelzang, 2010; Antonarakis and Eisenberger, 2013; Qi et al, 2015). In view of the lack of effective treatment for mCRPC, there is an urgent need for new, more effective therapeutic approaches especially aimed at reducing or eliminating prostate cancer metastasis.

Aneustat (OMN54) is a first-in-class multivalent immunooncology therapeutic, which is a mixture of extracts of three Chinese medicinal herbs, Ganoderma lucidum, Salvia miltiorrhiza and Scutellaria barbata, developed by Omnitura Therapeutics (Burlingame, CA, USA). Recently, Aneustat was shown to be well tolerated by patients in a Phase-I Clinical Trial (NCTId: NCT01555242) (Renouf et al, 2015). As patient-derived xenograft (PDX) cancer models have been strongly promoted by the NCI for anticancer drug screening (Ledford, 2016), the LTL-313H subrenal capsule PDX metastatic prostate cancer model, a highly clinically relevant model (Lin et al, 2014) (http://www.livingtumorcentre.$\mathrm{com} /$ ), was used to investigate anti-prostate cancer activity of docetaxel and Aneustat, used as single agents and in combination. It was found that a combination of Aneustat and docetaxel can lead to much higher tumour growth-inhibitory activity than the combined activities of the individual drugs, without inducing major host toxicity (Qu et al, 2014). Further analysis indicated that the combination of docetaxel and Aneustat could target multiple pathways and hallmarks of cancer that were not affected by the individual drugs (Qu et al, 2014).

In the present study, the LTL-313H subrenal capsule xenograft model was used to investigate the effects of docetaxel + Aneustat on prostate cancer metastasis and underlying molecular processes. It was found that treatment with docetaxel + Aneustat significantly inhibited lung micro-metastasis, kidney tissue invasion and, in particular, suppressed the expression of FOXM1, a gene generally considered to be a major promoter of cancer metastasis (Raychaudhuri and Park, 2011).

\section{MATERIALS AND METHODS}

Materials. Chemicals, solvents and solutions were purchased from Sigma-Aldrich, Oakville, ON, Canada, unless otherwise indicated.
Aneustat was supplied by Omnitura Therapeutics Inc. (Henderson, NV); and docetaxel was purchased from Sanofi-Aventis Canada (Laval, QC, Canada).

Cell culture. Human C4-2 metastatic, androgen-independent prostate cancer cells were obtained from the American Type Culture Collection (ATCC; Manassas, VA, USA). They were maintained as monolayer cultures in RPMI-1640 medium (HyClone, GE Healthcare Life Sciences; Mississauga, ON, Canada) supplemented with foetal bovine serum $(10 \%)$ at $37^{\circ} \mathrm{C}$ in a humidified incubator with a $5 \% \mathrm{CO}_{2}$ atmosphere.

IC50s of docetaxel, Aneustat and docetaxel + Aneustat determined with C4-2 cell cultures. C4-2 single cell suspensions were seeded into 6-well culture plates (starting concentration $\sim 2.5 \times 10^{5}$ cells per well) and incubated at $37^{\circ} \mathrm{C}$ in $5 \% \mathrm{CO}_{2}$ for $24 \mathrm{~h}$. Docetaxel and Aneustat (dissolved in DMSO + ethanol) were then added to the cultures as single drugs at a range of concentrations for a further $48 \mathrm{~h}$ incubation to assess the effects of the drugs on cell numbers; DMSO + ethanol was used as a vehicle control. Cell cultures were trypsinised to obtain single cell suspensions and then counted using a TC20 Automated Cell Counter (Bio-Rad, Mississauga, ON, Canada); cell viability was determined via Trypan blue exclusion. The IC50s of C4-2 cell cultures treated with docetaxel and Aneustat for $48 \mathrm{~h}$ were estimated using GraphPad Prism 5 (GraphPad Software, Inc., La Jolla, CA, USA). To determine the dosage of docetaxel and Aneustat in the combination, a fixed ratio of docetaxel and Aneustat (approximating IC $50_{\text {docetaxel }} / \mathrm{IC} 50_{\text {Aneustat }}$ ) was applied as a way to manage the dosage of the combination (Musende et al, 2010). Similarly, the IC50 of a $48 \mathrm{~h}$ treatment with the drug combination was obtained. Using CalcuSyn software (Biosoft, Cambridge, UK), the combination index (CI) was assessed to determine an additive effect $(\mathrm{CI}=1)$, synergism $(\mathrm{CI}<1)$, or antagonism (CI $>1)$ for the drug combination (Chou, 2006, 2010).

Wound-healing assay. A wound-healing assay was performed following procedures previously reported (Chiang et al, 2014). Replicate C4-2 cell cultures were incubated for $48 \mathrm{~h}$ with vehicle control, docetaxel $(5 \mathrm{~nm})$, Aneustat $\left(100 \mu \mathrm{g} \mathrm{ml}^{-1}\right)$ or a combination of docetaxel $(5 \mathrm{~nm})$ and Aneustat $\left(100 \mu \mathrm{g} \mathrm{ml}^{-1}\right)$. After this treatment, each culture was trypsinised into a single cell suspension. Cells from each group were seeded into 12-well culture plates $\left(\sim 7.5 \times 10^{5}\right.$ cells per well $)$ and incubated at $37^{\circ} \mathrm{C}$ in a $5 \% \mathrm{CO}_{2}$ atmosphere. Following cell attachment, the medium was replaced with serum-free medium. The next day, a 'wound' was created with a pipette tip in the middle of a confluent cell monolayer. Cell debris was removed by washing with $1 \times$ PBS ( 2 to 3 times) and images were taken at various time points using a Zeiss AxioObserver.Z1 microscope (Carl Zeiss, Toronto, ON, Canada). The cell migration area was analysed using ImageJ (National Institutes of Health, Bethesda, MD, USA). The percentages of migration areas at various time points were normalised to time 0 .

Histopathology and immunohistochemistry. Preparation of paraffin-embedded tissue sections and immunohistochemical analyses were carried out as previously described (Wang et al, 2005b). For histopathology, routine haematoxylin and eosin (H\&E) staining was used. The anti-human mitochondria antibody (MAB1273, Millipore, Etobicoke, ON, Canada) was used for identification of patient cancer cells. All sections used for immunohistochemistry were lightly counterstained with $5 \%$ (w/ v) Harris haematoxylin (Leica Biosystems; Concord, ON, Canada).

Mouse lung micro-metastasis and kidney tissue invasion in the LTL-313H xenograft model. As previously described ( $\mathrm{Qu}$ et al, 2014), NOD-SCID mice carrying LTL-313H xenografts were treated for 3 weeks with vehicle control, docetaxel $\left(5 \mathrm{mg} \mathrm{kg}^{-1}\right)$, Aneustat $\left(1652 \mathrm{mg} \mathrm{kg}^{-1}\right)$ or the combination of docetaxel 
$\left(5 \mathrm{mg} \mathrm{kg}^{-1}\right) /$ Aneustat $\left(1652 \mathrm{mg} \mathrm{kg}^{-1}\right)$. Animal care and experimental procedures were carried out in accordance with the guidelines of the Canadian Council on Animal Care (CCAC) under the approval of the Animal Care Committee of the University of British Columbia. Anti-human mitochondria antibody was used to identify human prostate cancer cells in mouse lung tissues. Groups of positively stained cells, with cell numbers $>4$, were considered lung micro-metastases. Five fields of each slide were randomly chosen and images taken $(\times 400)$, using an AxioCam HR CCD mounted on an Axioplan 2 microscope and Axiovision 3.1 software (Carl Zeiss). The numbers of mouse lung micrometastases were counted in each group and analysed. As shown in Figure 1, host (mouse) kidney tissue invasion analysis was carried out as follows: (i) images were taken using low power magnification; (ii) normal mouse kidney tissue areas were identified within tissue sections under high power magnification (see arrows in Figure 1) and a curve connecting the areas was drawn to mark the original mouse kidney boundary; (iii) any xenograft tissue observed beyond the curve was considered invading tumour tissue, and the proportion of invasive area was analysed. Host toxicity was estimated on the basis of weight changes and behavior, as previously reported (Qu et al, 2014).

Microarray data analysis. Gene expression microarray data obtained in the previous study with LTL-313H prostate cancer xenografts (Qu et al, 2014) were used. A total of 1757 genes were found, which showed $\geqslant 2$-fold changes in expression in response to treatment of the xenografts with docetaxel + Aneustat (compared to controls), that is, 919 upregulated genes and 838 downregulated genes. To compare the gene expression profiles obtained from docetaxel + Aneustat-treated LTL-313H xenografts with those from clinical patients, upregulated genes and downregulated genes were uploaded onto the Oncomine database (Rhodes et al, 2007). To investigate the molecular action of docetaxel + Aneustat, the 1757 genes with $\geqslant 2$-fold expression changes were uploaded onto the Ingenuity Pathway Analysis (IPA) program, and upstream regulator analysis was used to identify potential cancer driver genes for this data set (Krämer et al, 2014).

Quantitative real-time PCR. Total RNA was extracted using the RNeasy Mini Kit (Qiagen, Toronto, ON, Canada) and cDNA was synthesised using the QuantiTect Reverse Transcription Kit (Qiagen) according to the manufacturer's instructions. The primers used are described in Supplementary Table S1. qRT-PCR reactions using KAPA SYBR FAST Universal (Kapa Biosystems, Wilmington, MA, USA) were performed in triplicate in a ViiA 7 Real-Time PCR System (Applied Biosystems, Foster City, CA, USA). Expression levels of genes were normalised to that of GAPDH.

Western blot analysis. Whole cell and tissue protein extracts were resolved by SDS-PAGE using procedures previously reported $(\mathrm{Qu}$ et al, 2014). Proteins were then transferred to PVDF membranes. After blocking membranes for $1 \mathrm{~h}$ at room temperature in $5 \%$ milk in TBS/0.1\% Tween-20, they were incubated overnight at $4{ }^{\circ} \mathrm{C}$ with appropriate primary antibodies. Following incubation with the secondary antibody, immunoreactive proteins were visualised with a SuperSignal West Femto Maximum Sensitivity Substrate (Thermo Scientific, Rockford, IL, USA). The following antibodies were used: anti-FOXM1 (\#5436, rabbit monoclonal antibody, Cell Signaling Technology, Beverly, MA, USA) and anti-actin (A2066, rabbit polyclonal antibody, Sigma, Oakville, ON, Canada). Actin was used as a loading control.

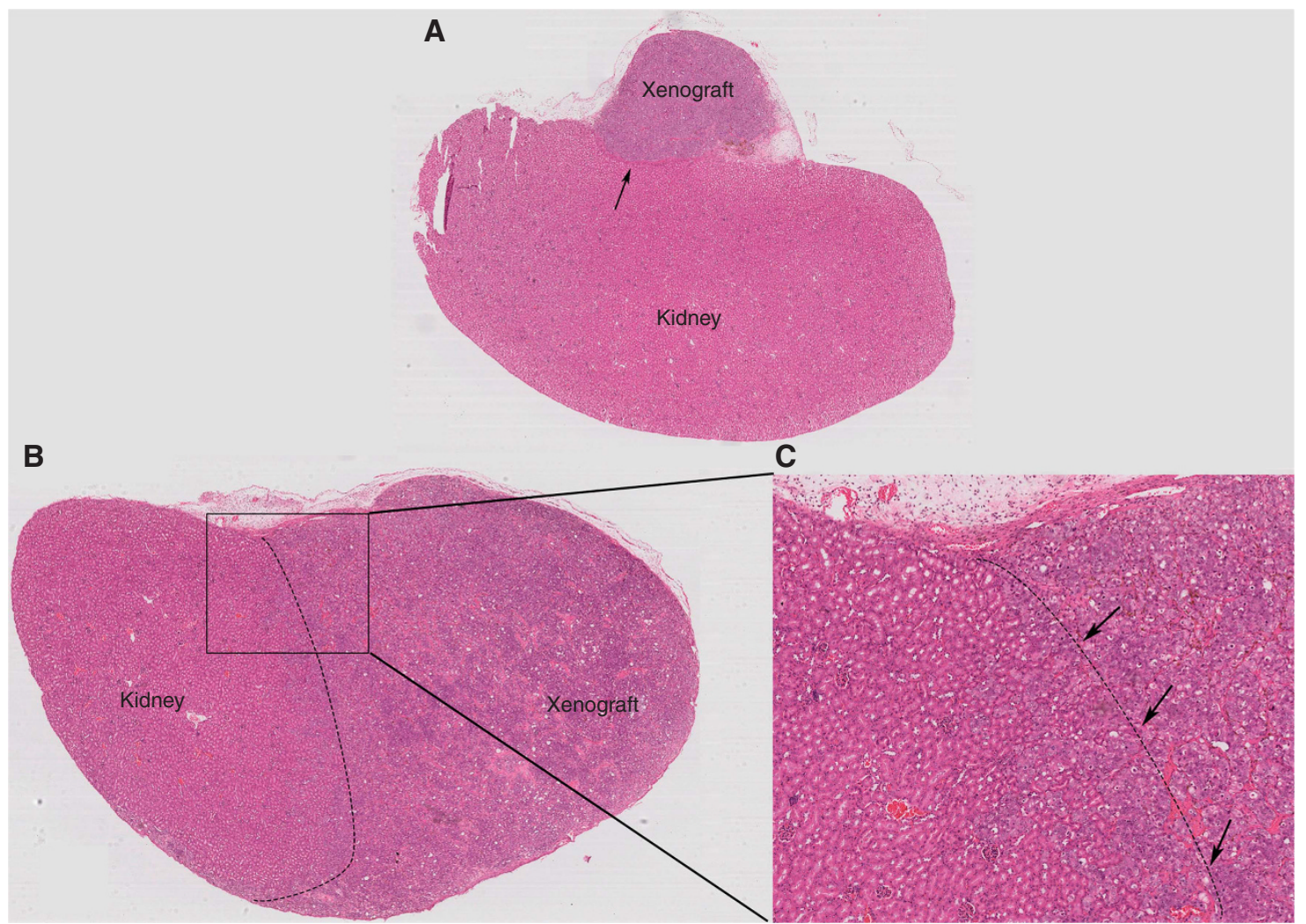

Figure 1. Section of host kidney engrafted with LTL-313H prostate cancer tissue. Boundaries between kidney and xenograft, (A) Clear boundary as indicated by arrows. (B) Fuzzy boundary indicated by the curve between kidney tissue (left) and xenograft tissue (right). (C) Magnified section, arrows indicate kidney residue areas. 
A

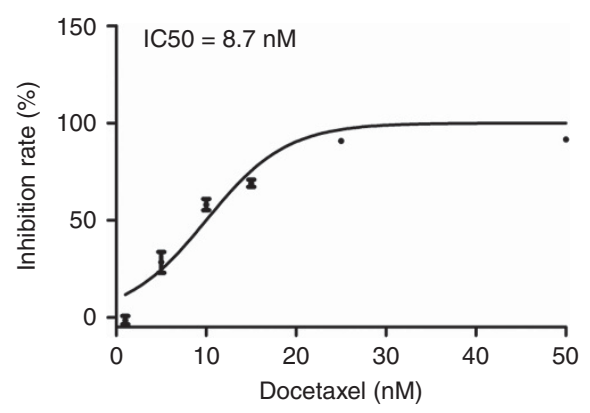

B

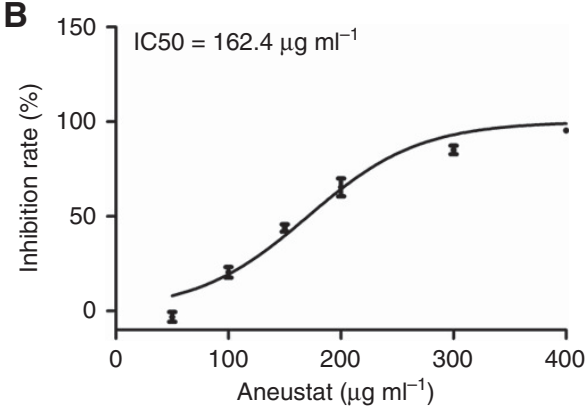

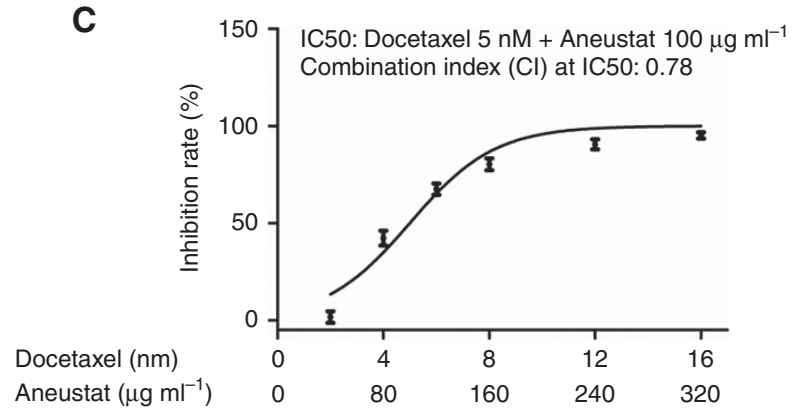

D

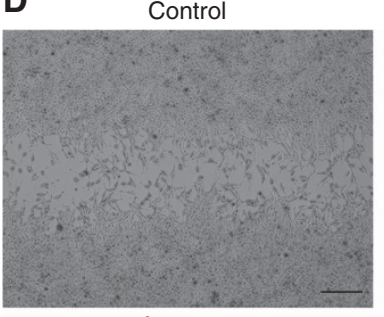

Aneustat

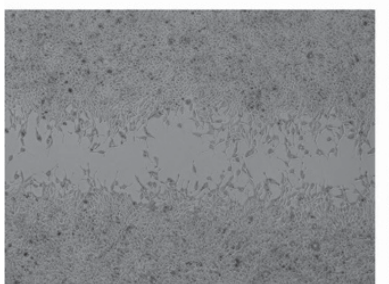

Docetaxel

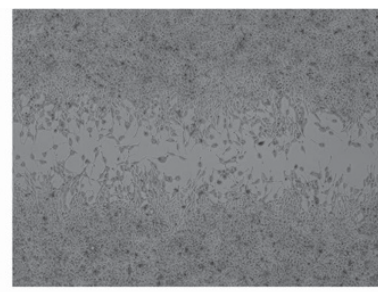

Docetaxel+Aneustat

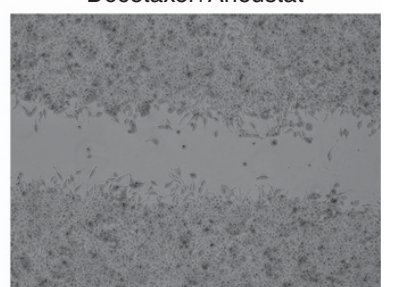

E

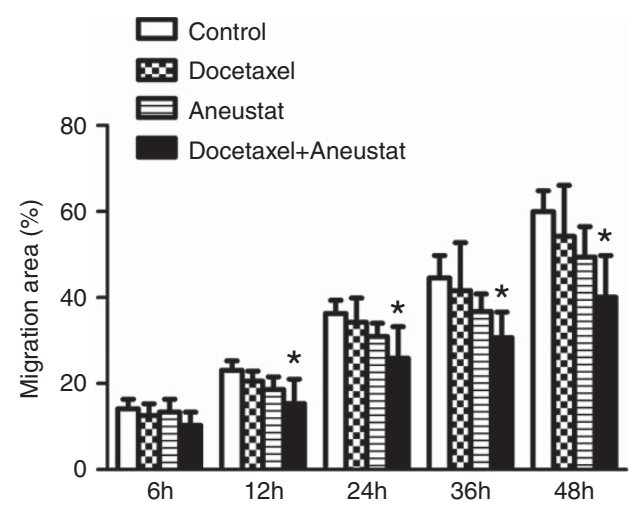

Figure 2. Effect of docetaxel + Aneustat on C4-2 cell proliferation and migration. Cells were cultured for $48 \mathrm{~h}$ with docetaxel (A), Aneustat (B) or the combination $(\mathbf{C})$ at various concentrations. The IC50 of each treatment was determined using GraphPad Prism 5. The combination index (Cl) was determined using CalcuSyn software $(\mathrm{Cl}=1$, additive effect; $\mathrm{Cl}<1$, synergism; $\mathrm{Cl}>1$, antagonism). Percentage growth inhibition is relative to the control. C4-2 cell cultures were incubated for $48 \mathrm{~h}$ with docetaxel $(5 \mathrm{~nm})$, Aneustat $\left(100 \mu \mathrm{g} \mathrm{ml}^{-1}\right)$ or the combination of docetaxel $(5 \mathrm{~nm})$ and Aneustat $\left(100 \mathrm{~g} \mathrm{ml}^{-1}\right)$ and a wound-healing assay was performed. (D) Images of cell migration into the wound area after $48 \mathrm{~h}$. (E) The percentage of cell-migrated wound areas is shown in the bar graph. One-way ANOVA was used for multiple group comparisons. The experiment was performed in triplicate. ${ }^{\star} P<0.05$ relative to control. Scale bar: $100 \mu \mathrm{m}$.

Overexpression of FOXM1 in C4-2 prostate cancer cells. As the isoform of FOXM1a is considered transcriptionally inactive (Kim et al, 2013), lentiviruses expressing FOXM1b and FOXM1c were produced by transfecting the respective plasmids in 293T cells as described in a previous study (Ci et al, 2015). Briefly, the pSinFOXM1b and pSin-FOXM1c expression vectors were constructed by a PCR approach with templates of pCW57.1-FOXM1b and pCW57.1-FOXM1c (Barger et al, 2015) purchased from Addgene (Cambridge, MA, USA), respectively. pSin-mCherry was used as a control. C4-2 cultures were infected with the viruses; puromycin in medium $\left(1 \mu \mathrm{g} \mathrm{ml}^{-1}\right)$ was applied for a $96 \mathrm{~h}$ incubation to obtain infected cell populations for treatment with drugs and subsequent analysis.

Boyden chamber migration assay. C4-2 cells infected with lentiviruses (pSin-mCherry, pSin-FOXM1b and pSin-FOXM1c) were treated for $48 \mathrm{~h}$ with the combination of docetaxel $(5 \mathrm{nM})$ and Aneustat $\left(100 \mu \mathrm{g} \mathrm{ml}^{-1}\right)$ or vehicle control. Live cells $\left(\sim 1 \times 10^{5}\right)$ from each group were then seeded into the Boyden Chamber insert (24-well plate; BD Bioscience). After an $18 \mathrm{~h}$ incubation at $37^{\circ} \mathrm{C}$ in a $5 \% \mathrm{CO}_{2}$ incubator, cells were fixed with $4 \%$ paraformaldehyde. Non-migrated cells on the upper surface of the membranes were removed and migrated cells on the lower surface of the membranes were stained with $0.1 \%$ crystal violet. Using a microscope, five pictures of each chamber were taken, and migrated cells were counted via Image J software (National Institutes of Health, Bethesda, MD, USA).

Statistics. Statistical analyses of gene expression data were performed as described above. The Student's $t$-test was carried out to compare means between two groups. One-way ANOVA was used to compare means of more than two groups. Results were 
A
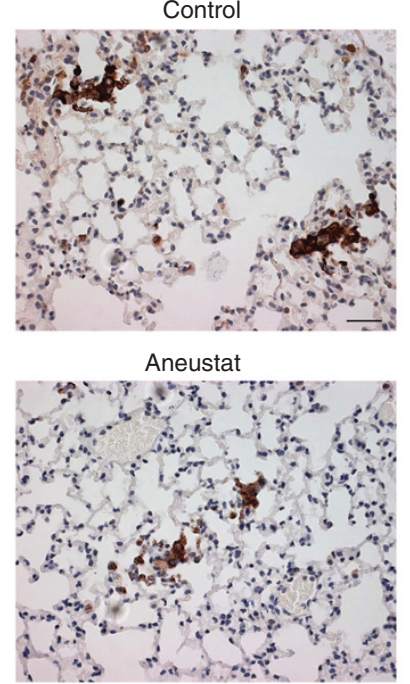

B

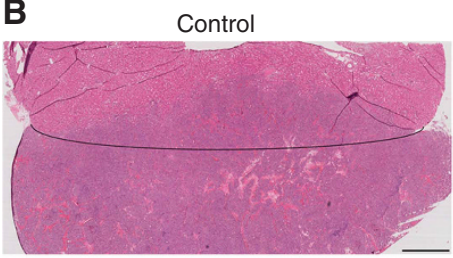

Aneustat

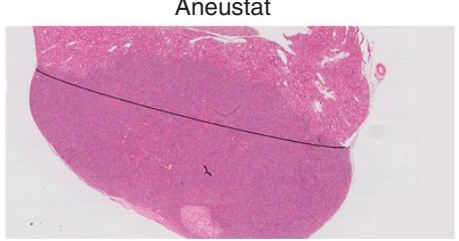

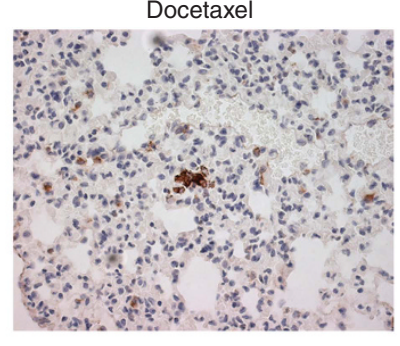

Docetaxel+Aneustat

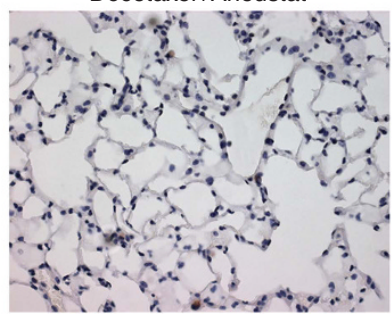

Docetaxel

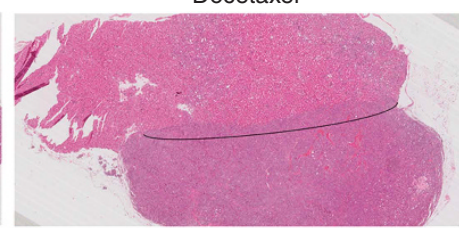

Docetaxel+Aneustat

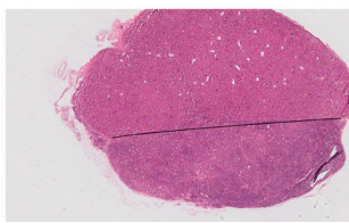

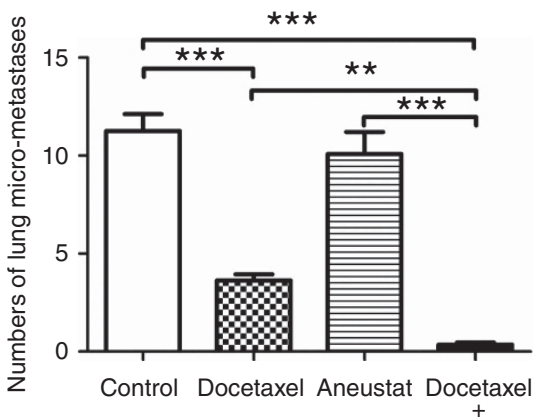

Aneustat

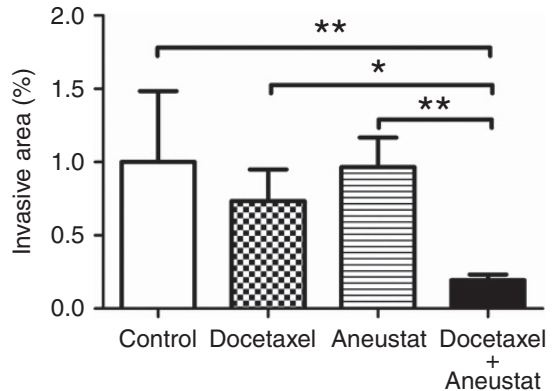

Figure 3. Effects of a 3-week treatment with docetaxel, Aneustat and docetaxel + Aneustat on lung micro-metastases in sections of lung tissue and on host adjacent kidney tissue invasion by prostate cancer cells in the LTL-313H model. (A) The effect of the drugs on the number of mouse lung micro-metastases as identified by positive staining of mitochondria via specific, anti-human mitochondria antibody using mouse lung tissue sections of the LTL-313H PDX prostate cancer model. Scale bar: $20 \mu \mathrm{m}$. (B) Kidney tissues (upper sections) and xenograft tissues (lower sections) of the LTL-313H PDX prostate cancer model treated with: control, docetaxel, Aneustat or docetaxel + Aneustat. One-way ANOVA was used for multiple group comparisons. Scale bar: $1 \mathrm{~mm}$. ${ }^{\star} P<0.05 ;{ }^{\star \star} P<0.01,{ }^{\star \star \star} P<0.001$.

considered statistically significant when $P<0.05$ and are expressed as means \pm s.e.m.

\section{RESULTS}

Synergistic inhibition by docetaxel and Aneustat of human C4-2 prostate cancer cell proliferation. C4-2 prostate cancer cell proliferation was inhibited, in a dose dependent manner, by treatment with docetaxel and Aneustat used as single drugs (Figure 2A and B). Using GraphPad Prism 5 to calculate the IC50s of the drugs used for a $48 \mathrm{~h}$ period, an IC50 of $8.7 \mathrm{nM}$ was found for docetaxel and an IC50 of $162.4 \mu_{\mathrm{g} \mathrm{ml}}^{-1}$ for Aneustat (Figure $2 \mathrm{~A}$ and $\mathrm{B}$ ). With a fixed ratio of docetaxel:Aneustat (approximating IC $50_{\text {docetaxel }} / \mathrm{IC} 50_{\text {Aneustat }}$ ), a series of concentrations of docetaxel plus Aneustat was administrated to C4-2 cell cultures for a $48 \mathrm{~h}$ incubation (Figure 2C). The IC50 of this combination was docetaxel $5 \mathrm{nM} /$ Aneustat $100 \mu \mathrm{g} \mathrm{ml}^{-1}$. As calculated using CalcuSyn software, the CI of docetaxel + Aneustat at the IC50 is $<1 \quad(0.78$; Figure $2 \mathrm{C})$, indicating that the combination of the drugs had a synergistic effect.

Inhibition by docetaxel + Aneustat of C4-2 cell migration in vitro. Replicate C4-2 prostate cancer cell cultures were incubated for $48 \mathrm{~h}$ with docetaxel $(5 \mathrm{nM})$ and Aneustat $\left(100 \mu \mathrm{g} \mathrm{ml}^{-1}\right)$ as single agents and with the combination of the drugs. Using the wound-healing assay, the migration areas of the C4- 2 cells at various time points $(0,6,12,24,36$ and $48 \mathrm{~h})$ were measured, and normalised to the wound area at time 0 . As shown in Figure 2D and E, the C4-2 cell motility in the wound-healing assay was significantly reduced $(P<0.05)$ (starting at $12 \mathrm{~h}$ ) by treatment of the cells with docetaxel + Aneustat as distinct from the single agents.

Lung micro-metastasis and kidney tissue invasion by LTL-313H prostate cancer cells inhibited by docetaxel + Aneustat. It has repeatedly been demonstrated that cells of LTL-313H subrenal capsule xenografts can invade the mouse host kidney tissue and metastasise to the lungs (Watahiki et al, 2011; Lin et al, 2014). Metastasising LTL-313H cells can be identified by positive staining for human mitochondria (via IHC using specific anti-human mitochondria antibody). In the present study it was found that, as shown in Figure 3A, treatment with docetaxel, as distinct from Aneustat, markedly reduced $(\sim 67 \%)$ the number of lung micrometastases (compared to controls). Furthermore, the combination of docetaxel and Aneustat led to a much higher reduction ( 99\%) in lung micro-metastases relative to the control $(P<0.001)$. As well, it was found that treatment with docetaxel + Aneustat, in 
contrast to docetaxel or Aneustat alone, markedly inhibited the invasion of kidney tissue by the grafted cells (Figure 3B), as measured by invasion of the mouse kidney tissue (Figure 1).

Gene expression profile of docetaxel + Aneustat-treated LTL313H xenografts: correlation with gene expression profiles of patients with improved outcome (Oncomine). Two gene expression profiles were obtained from LTL-313H prostate cancer xenografts treated with docetaxel + Aneustat, involving (i) 838 downregulated genes and (ii) 919 upregulated genes (i.e., upregulated and downregulated genes showing significant changes in expression ( $\geqslant 2$-fold) in response to the treatment of the xenografts compared to the control). These gene profiles were then compared with gene expression profiles from prostate cancer patients obtained from the Oncomine database. It was found that the gene expression profiles obtained from the docetaxel + Aneustat-treated xenografts positively correlated with the expression profiles of (i) patients showing longer survival time or longer cancer recurrence time and (ii) patients carrying non-metastatic tumours (odds ratio $>2, P<1 \mathrm{E}-4$ ) (Table 1), that is, changes indicative of improved patient outcome. Taken together, the gene expression data indicate that treatment with docetaxel + Aneustat is associated with improved patient outcome.

Suppression of FOXM1 expression as a potential mechanism underlying the anti-metastatic effect of docetaxel + Aneustat. Following IPA analysis of the 1757 genes showing significant differential expression ( $\geqslant 2$-fold difference) between docetaxel + Aneustat-treated and control xenografts $(\mathrm{Qu}$ et al, 2014), 'Upstream regulators' of IPA analysis was used to identify cancer driver genes potentially affected by docetaxel + Aneustat. The top 10 genes (upstream regulators) identified are presented in Supplementary Table S2. In particular, the FOXM1 gene, important in the promotion of cancer metastasis (Raychaudhuri and Park, 2011), was substantially downregulated by treatment with docetaxel + Aneustat, with a large fold change of -7.469 . As well, IPA analysis was used to identify genes directly regulated by FOXM1 protein, that is, AURKB (Wang et al, 2005a), CCNB1 (Laoukili et al, 2005), CDC25C (Zhou et al, 2010; Grant et al, 2013), CENPA (Sun et al, 2016), CENPE (Grant et al, 2013), CENPF (Laoukili et al, 2005), PLK1 (Chen et al, 2013), PTTG1 (Zheng et al, 2015) and STMN1 (Carr et al, 2010; Li et al, 2014). It was found that the expressions of these genes were also downregulated as shown by the microarray data of docetaxel + Aneustat-treated LTL-313H xenografts compared to controls (Figure 4A). To confirm downregulation of FOXM1 by treatment with docetaxel + Aneustat, the expressions of FOXM1 and FOXM1-target genes in LTL-313H xenografts and C4-2 cells treated with the drug combination were further analysed. It was found that the mRNA and protein expressions of FOXM1 were significantly downregulated by treatment with docetaxel + Aneustat in both LTL-313H xenografts (Figure 4B) and C4-2 cells (Figure 5A). Furthermore, the expression levels of FOXM1-target genes were also significantly downregulated in LTL-313H xenografts following treatment with the drug combination (Figure 4C); similar results were obtained with C4-2 cells (Supplementary Figure S1). Taken together, the results indicate that treatment of prostate cancer cells with docetaxel + Aneustat markedly reduced the expression of FOXM1, a metastasis-promoting driver gene (Raychaudhuri and Park, 2011).

FOXM1 overexpression attenuates docetaxel + Aneustatinduced inhibition of C4-2 cell migration. As shown in Figures $5 \mathrm{~B}, \mathrm{C} 4-2$ cells infected by lentiviruses pSin-FOXM1b or pSinFOXM1c overexpress FOXM1. Such C4-2 cells and vector control pSin-mCherry-infected C4-2 cells were treated for $48 \mathrm{~h}$ with the combination of docetaxel $(5 \mathrm{nM})$ and Aneustat $\left(100 \mu \mathrm{g} \mathrm{ml}^{-1}\right)$ or with vehicle control. The Boyden Chamber cell migration assay
Table 1. Correlation between treatment with the

combination of docetaxel and Aneustat and prostate cancer patient outcome (Oncomine)

\begin{tabular}{|l|l|l|l|l|}
$\begin{array}{l}\text { Clinical } \\
\text { event }\end{array}$ & Clinical cohort & $P$ value & $q$ value & $\begin{array}{l}\text { Risk of poor } \\
\text { outcome }\end{array}$ \\
\hline
\end{tabular}

Correlation with downregulated genes by treatment with the combination $^{\text {a }}$

\begin{tabular}{|c|c|c|c|c|}
\hline \\
\hline $\begin{array}{l}\text { Survival } \\
\quad>5 \text { years }\end{array}$ & Setlur Prostate & $8.53 E-21$ & $5.13 E-19$ & 3.9 \\
\hline$>5$ years & $\begin{array}{l}\text { Nakagawa } \\
\text { Prostate }\end{array}$ & $2.12 E-10$ & $7.72 E-9$ & 21.0 \\
\hline$>5$ years & $\begin{array}{l}\text { Nakagawa } \\
\text { Prostate } 2\end{array}$ & $1.18 E-5$ & $2.84 \mathrm{E}-4$ & 10.3 \\
\hline \multirow{2}{*}{$\begin{array}{r}\text { Recurrence } \\
>5 \text { years } \\
>5 \text { years }\end{array}$} & Taylor Prostate 3 & $5.28 E-35$ & $5.05 E-33$ & 11.1 \\
\hline & $\begin{array}{l}\text { Nakagawa } \\
\text { Prostate }\end{array}$ & $3.33 E-9$ & $1.12 \mathrm{E}-7$ & 9.9 \\
\hline \multicolumn{5}{|l|}{ Metastasis } \\
\hline & Taylor Prostate 3 & $1.12 E-104$ & $8.23 E-102$ & 9.4 \\
\hline & $\begin{array}{l}\text { Varambally } \\
\text { Prostate }\end{array}$ & $7.45 E-47$ & $9.95 E-45$ & 4.0 \\
\hline & Grasso Prostate & $1.10 E-44$ & $1.37 E-42$ & 3.9 \\
\hline & $\begin{array}{l}\text { LaTulippe } \\
\text { Prostate }\end{array}$ & $6.28 E-39$ & $6.65 E-37$ & 7.1 \\
\hline & Vanaja Prostate & $1.28 \mathrm{E}-34$ & $1.21 E-32$ & 3.4 \\
\hline & $\begin{array}{l}\text { Holzbeierlein } \\
\text { Prostate }\end{array}$ & $2.14 \mathrm{E}-14$ & $9.86 E-13$ & 3.4 \\
\hline \multicolumn{5}{|c|}{$\begin{array}{l}\text { Correlation with upregulated genes by treatment with the } \\
\text { combination }^{\text {b }}\end{array}$} \\
\hline $\begin{array}{l}\text { Recurrence } \\
>5 \text { years }\end{array}$ & Taylor Prostate 3 & $6.59 E-7$ & $6.82 E-5$ & 2.1 \\
\hline \multirow[t]{6}{*}{ Metastasis } & & & & \\
\hline & Tamura Prostate & $2.71 E-10$ & $8.43 E-8$ & 2.8 \\
\hline & Taylor Prostate 3 & $3.83 E-21$ & $1.71 \mathrm{E}-17$ & 3.5 \\
\hline & Yu Prostate & $1.43 E-5$ & $8.73 E-4$ & 2.5 \\
\hline & Grasso Prostate & $1.42 E-11$ & $6.19 E-9$ & 2.2 \\
\hline & $\begin{array}{l}\text { LaTulippe } \\
\text { Prostate }\end{array}$ & $3.62 \mathrm{E}-8$ & $5.94 \mathrm{E}-6$ & 2.4 \\
\hline
\end{tabular}

${ }^{\mathrm{a}}$ The calculation was based on downregulated genes following treatment with the combination and top $10 \%$ over-expressed genes in a short survival time, short recurrence time and metastatic prostate cancer patient cohorts.

$\mathbf{b}_{\text {The calculation was based on genes upregulated by treatment with the combination and }}$ top $10 \%$ under-expressed genes in a short survival time, short recurrence time and metastatic prostate cancer patient cohorts.

was applied to determine the effects of the treatment with docetaxel + Aneustat on cell motility. The C4-2 cells that overexpressed FOXM1b/FOXM1c, and had been treated with docetaxel + Aneustat, showed higher migration ability compared to the pSin-mCherry control cells (Figure 5C), indicating that overexpression of FOXM1 can reduce the inhibitory effect of docetaxel + Aneustat on cell motility.

Furthermore, treatment of the pSin-mCherry vector control cells with docetaxel + Aneustat led to reduction of the expression of the FOXM1-target genes. In contrast, all of the FOXM1-target genes showed higher expression when FOXM1b or FOXM1c were over-expressed (Figure 5D). Taken together, the results indicate that FOXM1, a gene encoding a key transcription factor, is a major cancer driver gene that is affected by treatment with docetaxel + Aneustat as distinct from the individual drugs.

\section{DISCUSSION}

On the basis of a previous study showing that combining docetaxel with Aneustat can lead to much higher prostate cancer growthinhibitory activity than the combined activities of the individual 
A
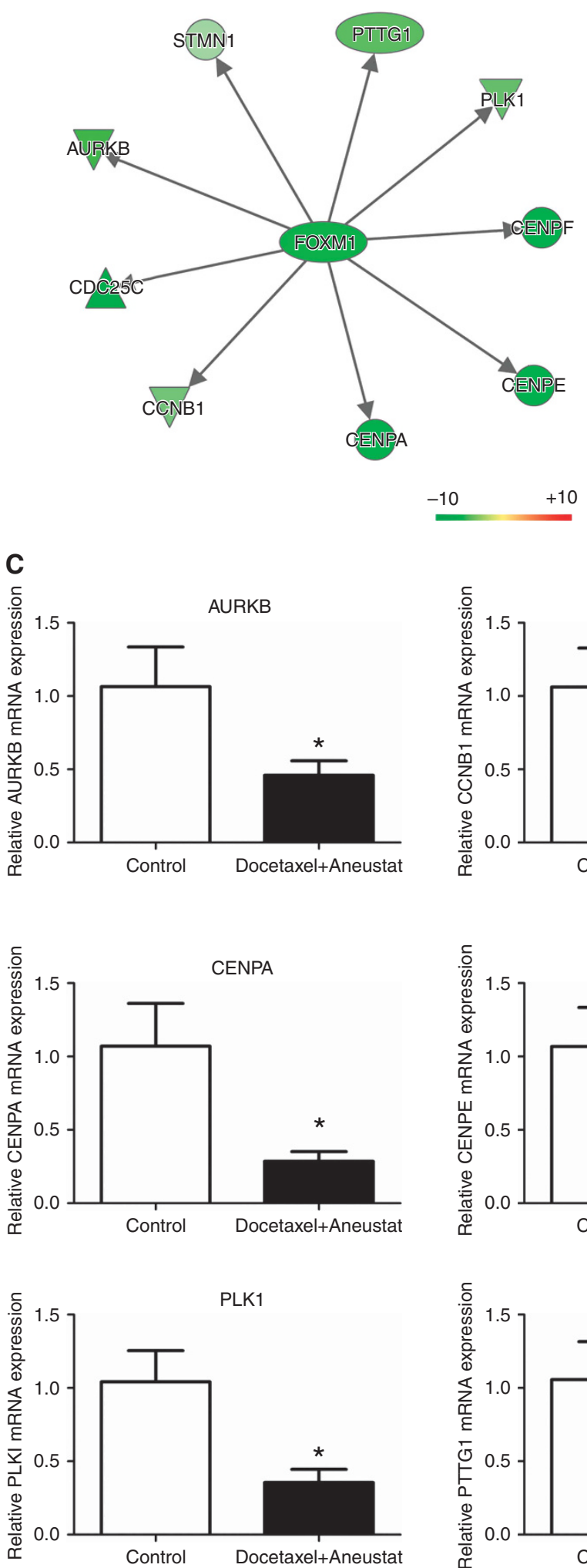
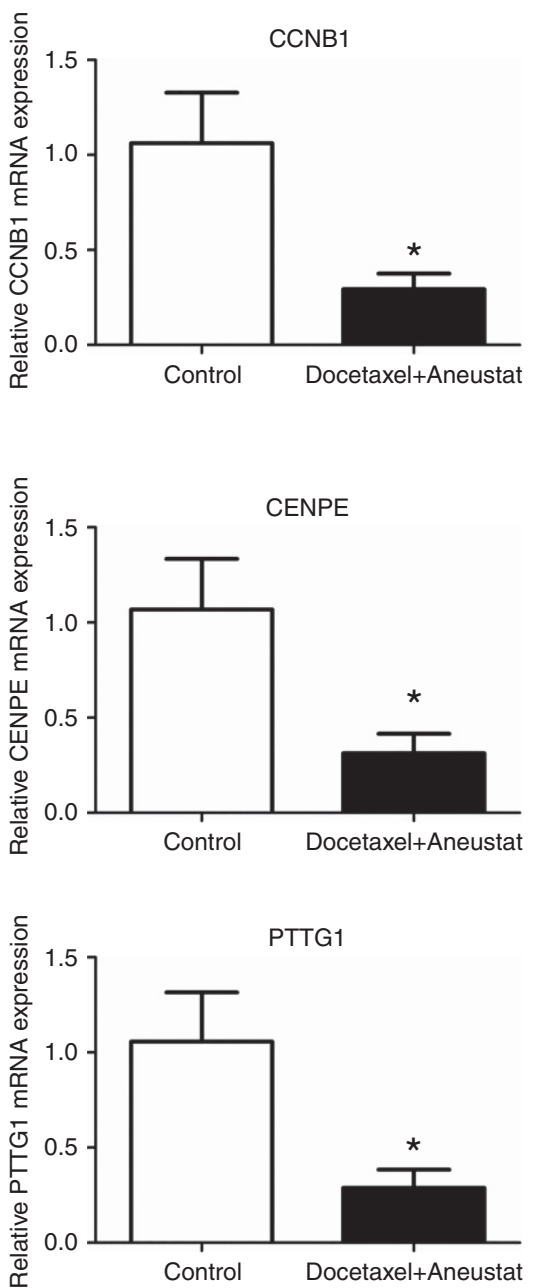
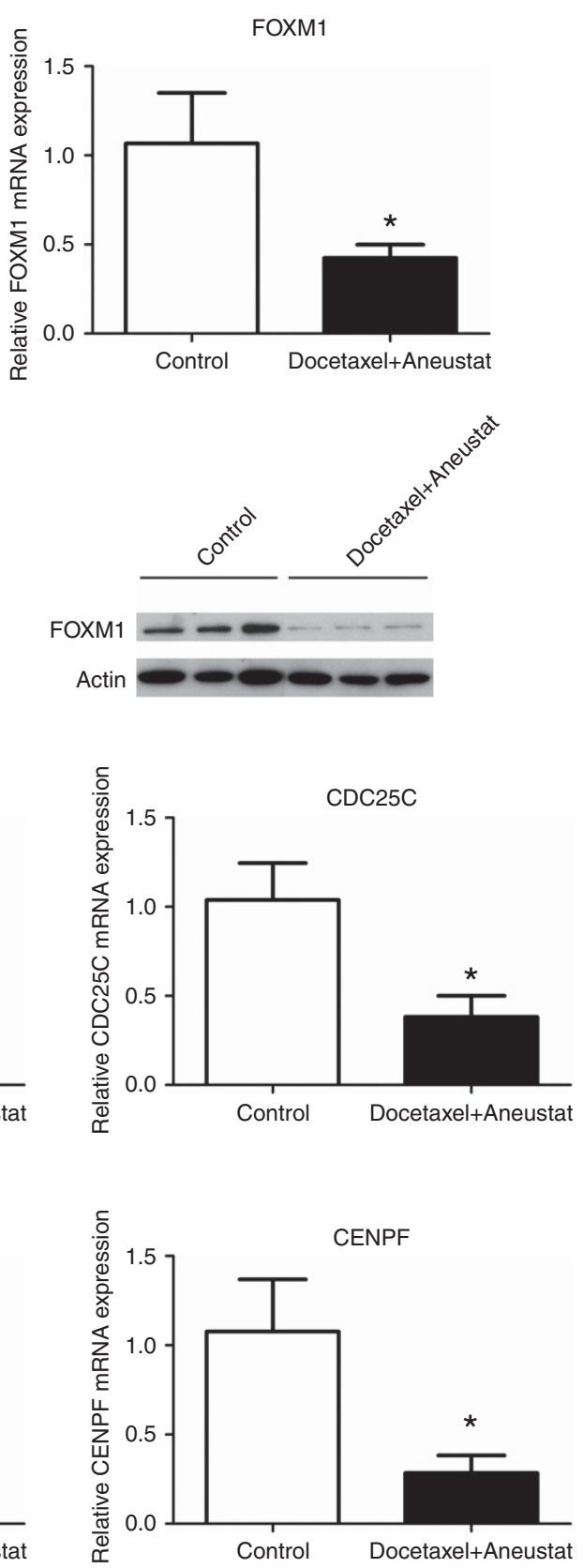

FOXM1

Actin

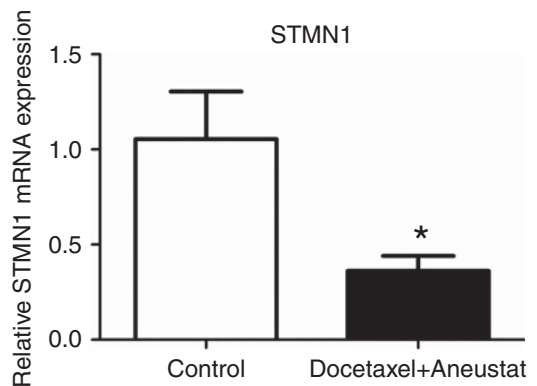

Figure 4. Effect of docetaxel + Aneustat on the expressions of FOXM1 and FOXM1-target genes in LTL-313H xenografts. (A) Genes transcriptionally regulated by FOXM1 protein as predicted by IPA; green indicates downregulation of genes based on microarray data obtained with docetaxel + Aneustat-treated LTL-313H xenografts (Qu et al, 2014). (B) mRNA and protein expression of FOXM1 in LTL-313H xenografts, and (C) the mRNA levels of FOXM1-target genes. The experiment was performed in triplicate. ${ }^{\star} P<0.05$. 
A

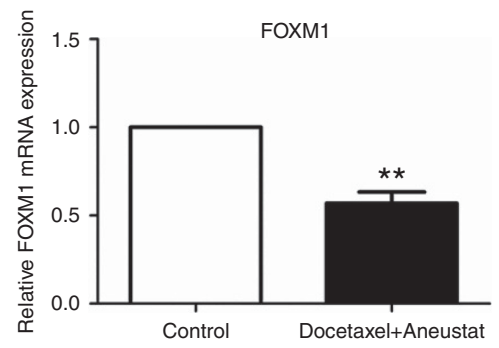

C
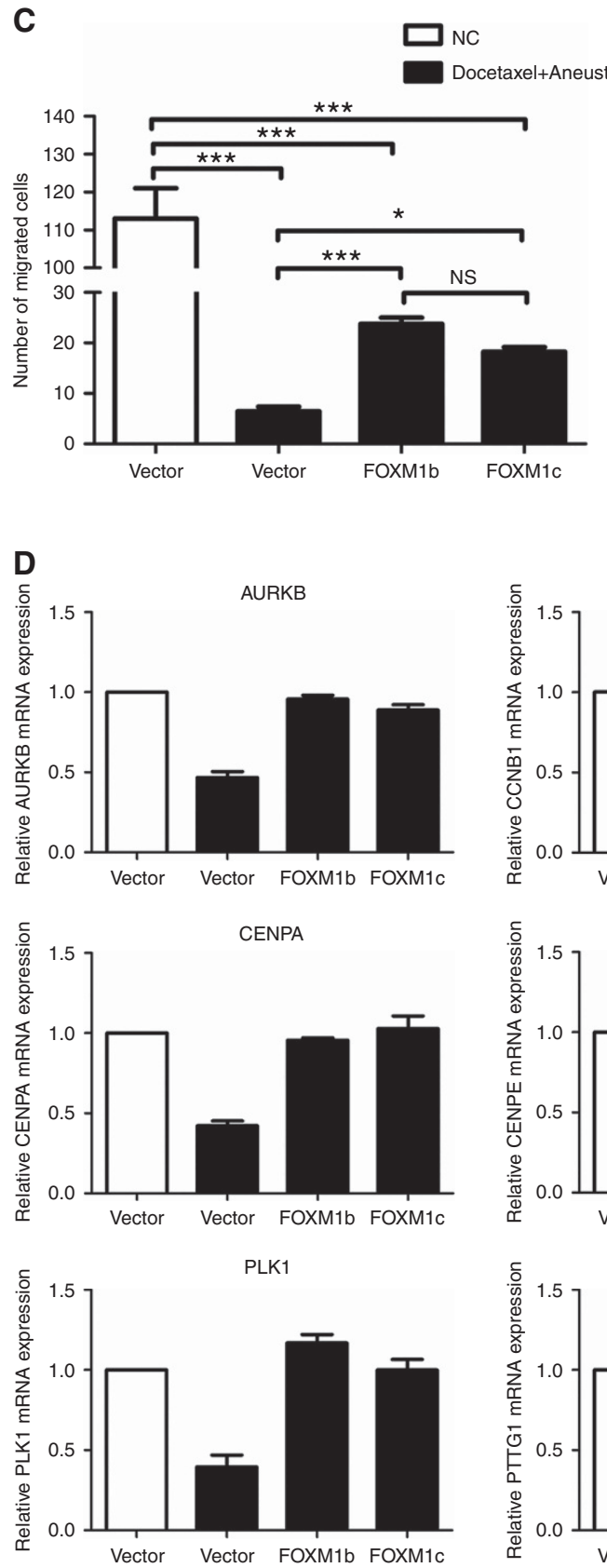
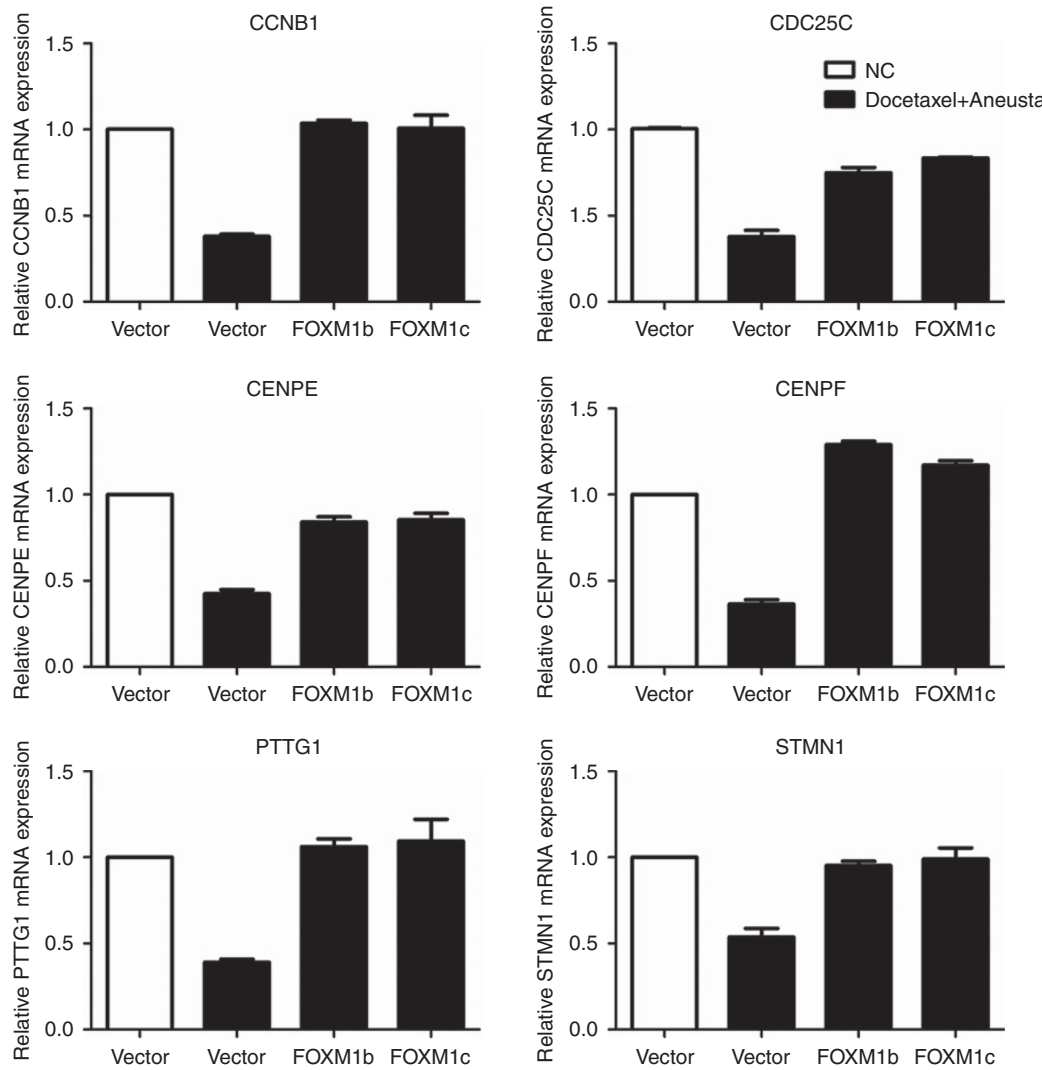

B

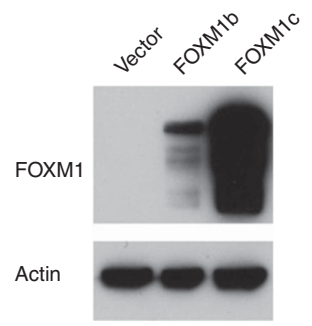

Docetaxel+Aneustat

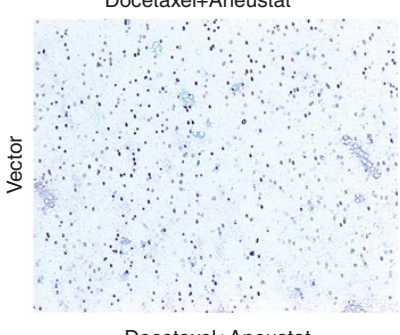

Docetaxel+Aneustat

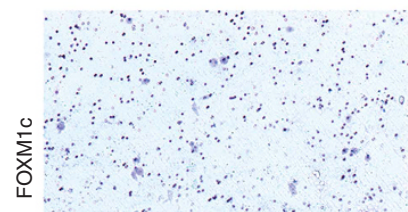

Figure 5. Effects of treatment with docetaxel + Aneustat on FOXM1 overexpressing C4-2 cells. (A) mRNA and protein expression of FOXM1 in C4-2 cells treated with docetaxel + Aneustat for $48 \mathrm{~h}$. (B) C4-2 cells infected with pSin-FOXM1b and pSin-FOXM1c show overexpression of FOXM1b and FOXM1c protein. (C) Boyden Chamber cell migration assay of pSin-FOXM1b and pSin-FOXM1c C4-2 cells and pSin-mCherry control cells, treated and not-treated with docetaxel + Aneustat. (D) Effects of the treatment on mRNA expression of FOXM1-target genes in pSinmCherry, pSin-FOXM1b and pSin-FOXM1c C4-2 cells. The experiment was performed in triplicate. ${ }^{\star} P<0.05 ;{ }^{\star \star} P<0.01 ;{ }^{\star \star \star} P<0.001 ; \mathrm{NS}, \mathrm{no}$ statistical significance. Scale bar: $20 \mu \mathrm{m}$. 
drugs (Qu et al, 2014), the present study explored the effect of this drug combination on cancer metastasis. The findings that docetaxel + Aneustat can potently inhibit lung micro-metastasis by prostate cancer cells in the LTL-313H model (Figure 3A) and also host kidney tissue invasion (Figure $3 \mathrm{~B}$ ) are consistent with (i) the inhibition by docetaxel + Aneustat of C4-2 cell migration/ proliferation (Figure 2), and (ii) the findings of the previous study indicating that docetaxel + Aneustat would affect a variety of cancer hallmarks, including 'tissue invasion and metastasis' $(\mathrm{Qu}$ et al, 2014). As well, the inhibition by docetaxel + Aneustat of lung micro-metastasis and adjacent kidney tissue invasion in the LTL$313 \mathrm{H}$ PDX prostate cancer model (Figure 3) is in agreement with the prediction by Oncomine gene expression profile analysis in the present study that treatment with docetaxel + Aneustat is associated with improved patient outcome, as evidenced by longer survival time, longer disease relapse time and lack of metastasis development (Table 1). In view of the marked anti-prostate cancer growth activity of docetaxel + Aneustat without inducing major host toxicity (Qu et al, 2014) and its anti-metastatic efficacy observed in the present study, combined use of docetaxel and Aneustat appears to present a promising new therapeutic strategy for metastatic prostate cancer, a disease whose prognosis is currently grim.

The finding that treatment of the LTL-313H PDX prostate cancer model with docetaxel + Aneustat can markedly downregulate the expression of FOXM1 and also of its target genes, that is, $A U R K B, C C N B 1, C D C 25 C, C E N P A, C E N P E, C E N P F, P L K 1$, $P T T G 1$ and STMN1 (Figure 4), is consistent with the inhibition by docetaxel + Aneustat of lung micro-metastasis and adjacent kidney tissue invasion (Figure 3) as FOXM1 is considered an important promoter of metastasis (Raychaudhuri and Park, 2011), as are its target genes such as CENPA, PTTG1 and STMN1 (Zheng et al, 2015; Kuang et al, 2016; Sun et al, 2016). FOXM1 and its target gene $C E N P F$, in particular, have been identified as synergistic drivers of prostate cancer (Lokody, 2014), and overexpression of both FOXM1 and CENPF harbors a robust bad prognostic value indicative of poor patient survival and metastasis (Aytes et al, 2014). As well, overexpression of FOXM1 in C4-2 cells led to both upregulation of FOXM1-target genes and reduction of the antimigration activity of docetaxel + Aneustat (Figure 5), supporting the prediction by IPA that FOXM1 is a cancer driver gene that is affected by docetaxel + Aneustat (Supplementary Table S2). As an upstream regulator, FOXM1 has been shown to regulate a number of canonical pathways such as the 'mitotic roles of polo-like kinase' pathway (Qu et al, 2014), acting via PLK1 (polo-like kinase 1), a key factor in this pathway (Donaldson et al, 2001). The marked downregulation of PLK1 by docetaxel + Aneustat (Figure 4; Supplementary Figure S1) is in agreement with that. It has also been reported that downregulation of FOXM1 expression can inhibit aerobic glycolysis of cancers (Cui et al, 2014), consistent with our report that docetaxel + Aneustat can affect the glycolysis pathway (Qu et al, 2014). Furthermore, FOXM1 has been reported to be an upstream regulator of the expression of the androgen receptor (AR), which has a key role in prostate cancer progression (Watson et al, 2015). Ectopic expression of FOXM1 led to elevated expression of AR (Liu et al, 2017). In addition, silencing of FOXM1 can lead to decreased AR expression (Liu et al, 2014). In our previous study, it was shown that the expression of $A R$ was suppressed by docetaxel + Aneustat (Qu et al, 2014), which could be a downstream event of the downregulation of FOXM1 by docetaxel + Aneustat as shown in the current study. Recently, it has been shown that FOXM1 has an important role as a master regulator of PCS1 (prostate cancer subtype 1, a most aggressive and lethal subtype of prostate cancer) and Enzalutamide-resistant prostate cancer. Targeting FOXM1 with its inhibitor, Monensin, has been shown to reverse the PCS1 signature and its associated stem-like features and to reduce the growth of Enzalutamide- resistant prostate tumours (Ketola et al, 2017). FOXM1 deficiency in TRAMP mice has been shown to reduce prostate cancer metastasis (Cai et al, 2013). Taken together, it appears that inhibition of expression of FOXM1 and its target genes is one of the mechanisms underlying docetaxel + Aneustat-induced inhibition of prostate cancer tissue invasion and metastasis. As such, FOXM1 provides a novel target for therapy of metastatic prostate cancer and patients with FOXM1 dysregulation would likely benefit from the treatment.

Subcutaneous mouse xenograft models of human cancer are in general not considered suitable for studies of local tissue invasion, an important characteristic of metastasis (Smith and Thomas, 2006). In the present study, however, it was found, using an innovative histological approach (Figure 1), that subrenal capsule PDX cancer models can be used for studying local invasion of host kidney tissue - an observation that could lead to wider application.

In conclusion, the present study shows, using a high fidelity subrenal capsule PDX metastatic prostate cancer model, that combined use of docetaxel and Aneustat, as distinct from the individual drugs, can markedly inhibit metastasis and local tissue invasion - apparently a result of suppression of expression of metastasis driver genes such as FOXM1. As such, combined use of docetaxel and Aneustat may provide a novel, more effective regimen for therapy of advanced, metastatic prostate cancer. In addition, it was found that subrenal capsule PDX models can be used for studies of local tissue invasiveness.

\section{ACKNOWLEDGEMENTS}

This work is supported by the Canadian Institutes of Health Research (YW), Prostate Cancer Canada (CCC, YW), Terry Fox Research Institute (YW), BC Cancer Foundation (YW).

\section{CONFLICT OF INTEREST}

Dr. Yuzhuo Wang acted as a consultant for, and received a research fund from, Genyous Biomed International Inc. The remaining authors declare no conflict of interest.

\section{REFERENCES}

Antonarakis ES, Eisenberger MA (2013) Phase III trials with docetaxel-based combinations for metastatic castration-resistant prostate cancer: time to learn from past experiences. J Clin Oncol 31(14): 1709-1712.

Araujo JC, Trudel GC, Saad F, Armstrong AJ, Yu EY, Bellmunt J, Wilding G, McCaffrey J, Serrano SV, Matveev VB, Efstathiou E, Oudard S, Morris MJ, Sizer B, Goebell PJ, Heidenreich A, de Bono JS, Begbie S, Hong JH, Richardet E, Gallardo E, Paliwal P, Durham S, Cheng S, Logothetis CJ (2013) Docetaxel and dasatinib or placebo in men with metastatic castration-resistant prostate cancer (READY): a randomised, double-blind phase 3 trial. Lancet Oncol 14(13): 1307-1316.

Attard G, Parker C, Eeles RA, Schröder F, Tomlins SA, Tannock I, Drake CG, de Bono JS (2016) Prostate cancer. Lancet 387(10013): 70-82.

Aytes A, Mitrofanova A, Lefebvre C, Alvarez MJ, Castillo-Martin M, Zheng T, Eastham JA, Gopalan A, Pienta KJ, Shen MM, Califano A, Abate-Shen C (2014) Cross-species regulatory network analysis identifies a synergistic interaction between FOXM1 and CENPF that drives prostate cancer malignancy. Cancer Cell 25(5): 638-651.

Barger CJ, Zhang W, Hillman J, Stablewski AB, Higgins MJ, Vanderhyden BC, Odunsi K, Karpf AR (2015) Genetic determinants of FOXM1 overexpression in epithelial ovarian cancer and functional contribution to cell cycle progression. Oncotarget 6(29): 27613-27627.

Cai Y, Balli D, Ustiyan V, Fulford L, Hiller A, Misetic V, Zhang Y, Paluch AM, Waltz SE, Kasper S, Kalin TV (2013) Foxm1 expression in prostate epithelial cells is essential for prostate carcinogenesis. J Biol Chem 288(31): 22527-22541. 
Carr JR, Park HJ, Wang Z, Kiefer MM, Raychaudhuri P (2010) FoxM1 mediates resistance to herceptin and paclitaxel. Cancer Res 70(12): 5054-5063.

Chaffer CL, Weinberg RA (2011) A perspective on cancer cell metastasis. Science 331(6024): 1559-1564.

Chen X, Müller GA, Quaas M, Fischer M, Han N, Stutchbury B, Sharrocks AD, Engeland K (2013) The forkhead transcription factor FOXM1 controls cell cycle-dependent gene expression through an atypical chromatin binding mechanism. Mol Cell Biol 33(2): 227-236.

Chiang YT, Wang K, Fazli L, Qi RZ, Gleave ME, Collins CC, Gout PW, Wang Y (2014) GATA2 as a potential metastasis-driving gene in prostate cancer. Oncotarget 5(2): 451-461.

Chou TC (2006) Theoretical basis, experimental design, and computerized simulation of synergism and antagonism in drug combination studies. Pharmacol Rev 58(3): 621-681.

Chou TC (2010) Drug combination studies and their synergy quantification using the Chou-Talalay method. Cancer Res 70(2): 440-446.

Ci X, Xing C, Zhang B, Zhang Z, Ni JJ, Zhou W, Dong JT (2015) KLF5 inhibits angiogenesis in PTEN-deficient prostate cancer by attenuating AKT activation and subsequent HIF1 $\alpha$ accumulation. Mol Cancer 14: 91.

Cui J, Shi M, Xie D, Wei D, Jia Z, Zheng S, Gao Y, Huang S, Xie K (2014) FOXM1 promotes the warburg effect and pancreatic cancer progression via transactivation of LDHA expression. Clin Cancer Res 20(10): 2595-2606.

Donaldson MM, Tavares AA, Hagan IM, Nigg EA, Glover DM (2001) The mitotic roles of Polo-like kinase. J Cell Sci 114(Pt 13): 2357-2358.

Galsky MD, Vogelzang NJ (2010) Docetaxel-based combination therapy for castration-resistant prostate cancer. Ann Oncol 21(11): 2135-2144.

Grant GD, Brooks L, Zhang X, Mahoney JM, Martyanov V, Wood TA, Sherlock G, Cheng C, Whitfield ML (2013) Identification of cell cycleregulated genes periodically expressed in $\mathrm{U} 2 \mathrm{OS}$ cells and their regulation by FOXM1 and E2F transcription factors. Mol Biol Cell 24(23): 3634-3650.

Gravis G, Audenet F, Irani J, Timsit MO, Barthelemy P, Beuzeboc P, Fléchon A, Linassier C, Oudard S, Rebillard X, Richaud P, Rouprêt M, Thiery Vuillemin A, Vincendeau S, Albiges L, Rozet F (2016) Chemotherapy in hormone-sensitive metastatic prostate cancer: Evidences and uncertainties from the literature. Cancer Treat Rev 55: 211-217.

James ND, Sydes MR, Clarke NW, Mason MD, Dearnaley DP, Spears MR, Ritchie AW, Parker CC, Russell JM, Attard G, de Bono J, Cross W, Jones RJ, Thalmann G, Amos C, Matheson D, Millman R, Alzouebi M, Beesley S, Birtle AJ, Brock S, Cathomas R, Chakraborti P, Chowdhury S, Cook A, Elliott T, Gale J, Gibbs S, Graham JD, Hetherington J, Hughes R, Laing R, McKinna F, McLaren DB, O'Sullivan JM, Parikh O, Peedell C, Protheroe A, Robinson AJ, Srihari N, Srinivasan R, Staffurth J, Sundar S, Tolan S, Tsang D, Wagstaff J, Parmar MK, investigators S (2016) Addition of docetaxel, zoledronic acid, or both to first-line long-term hormone therapy in prostate cancer (STAMPEDE): survival results from an adaptive, multiarm, multistage, platform randomised controlled trial. Lancet 387(10024): 1163-1177.

Kelly WK, Halabi S, Carducci M, George D, Mahoney JF, Stadler WM, Morris M, Kantoff P, Monk JP, Kaplan E, Vogelzang NJ, Small EJ (2012) Randomized, double-blind, placebo-controlled phase III trial comparing docetaxel and prednisone with or without bevacizumab in men with metastatic castration-resistant prostate cancer: CALGB 90401. J Clin Oncol 30(13): 1534-1540.

Ketola K, Munuganti RSN, Davies A, Nip KM, Bishop JL, Zoubeidi A (2017) Targeting prostate cancer subtype 1 by forkhead box M1 pathway inhibition. Clin Cancer Res 23(22): 6923-6933.

Kim YH, Choi MH, Kim JH, Lim IK, Park TJ (2013) C-terminus-deleted FoxM1 is expressed in cancer cell lines and induces chromosome instability. Carcinogenesis 34(8): 1907-1917.

Krämer A, Green J, Pollard J, Tugendreich S (2014) Causal analysis approaches in Ingenuity Pathway Analysis. Bioinformatics 30(4): 523-530.

Kuang XY, Jiang HS, Li K, Zheng YZ, Liu YR, Qiao F, Li S, Hu X, Shao ZM (2016) The phosphorylation-specific association of STMN1 with GRP78 promotes breast cancer metastasis. Cancer Lett 377(1): 87-96.

Laoukili J, Kooistra MR, Brás A, Kauw J, Kerkhoven RM, Morrison A, Clevers H, Medema RH (2005) FoxM1 is required for execution of the mitotic programme and chromosome stability. Nat Cell Biol 7(2): 126-136.
Ledford H (2016) US cancer institute to overhaul tumour cell lines. Nature 530(7591): 391.

Lewis B, Chalhoub E, Chalouhy C, Sartor O (2015) Radium-223 in bonemetastatic prostate cancer: current data and future prospects. Oncology 29(7): 483-488.

Li X, Yao R, Yue L, Qiu W, Qi W, Liu S, Yao Y, Liang J (2014) FOXM1 mediates resistance to docetaxel in gastric cancer via up-regulating stathmin. J Cell Mol Med 18(5): 811-823.

Lin D, Wyatt AW, Xue H, Wang Y, Dong X, Haegert A, Wu R, Brahmbhatt S, Mo F, Jong L, Bell RH, Anderson S, Hurtado-Coll A, Fazli L, Sharma M, Beltran H, Rubin M, Cox M, Gout PW, Morris J, Goldenberg L, Volik SV, Gleave ME, Collins CC (2014) High fidelity patient-derived xenografts for accelerating prostate cancer discovery and drug development. Cancer Res 74(4): 1272-1283.

Liu Y, Gong Z, Sun L, Li X (2014) FOXM1 and androgen receptor co-regulate CDC6 gene transcription and DNA replication in prostate cancer cells. Biochim Biophys Acta 1839(4): 297-305.

Liu Y, Yuan B, Yin L, Peng Y, Yu X, Zhou W, Gong Z, Liu J, He L, Li X (2017) FOXM1 promotes the progression of prostate cancer by regulating PSA gene transcription. Oncotarget 8(10): 17027-17037.

Lokody I (2014) Signalling: FOXM1 and CENPF: co-pilots driving prostate cancer. Nat Rev Cancer 14(7): 450-451.

McKeage K (2012) Docetaxel: a review of its use for the first-line treatment of advanced castration-resistant prostate cancer. Drugs 72(11): 1559-1577.

Musende AG, Eberding A, Jia W, Ramsay E, Bally MB, Guns ET (2010) Rh2 or its aglycone aPPD in combination with docetaxel for treatment of prostate cancer. Prostate 70(13): 1437-1447.

Qi WX, Fu S, Zhang Q, Guo XM (2015) Efficacy and toxicity of molecular targeted therapies in combination with docetaxel for metastatic castrationresistant prostate cancer: a meta-analysis of phase III randomized controlled trials. J Chemother 27(3): 181-187.

Qu S, Wang K, Xue H, Wang Y, Wu R, Liu C, Gao AC, Gout PW, Collins CC, Wang Y (2014) Enhanced anticancer activity of a combination of docetaxel and Aneustat (OMN54) in a patient-derived, advanced prostate cancer tissue xenograft model. Mol Oncol 8(2): 311-322.

Quinn DI, Tangen CM, Hussain M, Lara PN, Goldkorn A, Moinpour CM, Garzotto MG, Mack PC, Carducci MA, Monk JP, Twardowski PW, Van Veldhuizen PJ, Agarwal N, Higano CS, Vogelzang NJ, Thompson IM (2013) Docetaxel and atrasentan versus docetaxel and placebo for men with advanced castration-resistant prostate cancer (SWOG S0421): a randomised phase 3 trial. Lancet Oncol 14(9): 893-900.

Ramos-Esquivel A, Fernández C, Zeledón Z (2016) Androgen-deprivation therapy plus chemotherapy in metastatic hormone-sensitive prostate cancer. A systematic review and meta-analysis of randomized clinical trials. Urol Oncol 34(8335): e9-335.e19.

Raychaudhuri P, Park HJ (2011) FoxM1: a master regulator of tumor metastasis. Cancer Res 71(13): 4329-4333.

Renouf D, Kollmannsberger C, Chi K, Chia S, Tinker A, Mitchell T, Lam S, Joshi T, Kwok D, Ostrem J, Sutcliffe S, Gelmon K (2015) Abstract C41: A phase 1 study of OMN54 in patients with advanced malignancies. Mol Cancer Therap 14(12 Suppl 2): C41-C41.

Rhodes DR, Kalyana-Sundaram S, Mahavisno V, Varambally R, Yu J, Briggs BB, Barrette TR, Anstet MJ, Kincead-Beal C, Kulkarni P, Varambally S, Ghosh D, Chinnaiyan AM (2007) Oncomine 3.0: genes, pathways, and networks in a collection of 18,000 cancer gene expression profiles. Neoplasia 9(2): 166-180.

Smith LP, Thomas GR (2006) Animal models for the study of squamous cell carcinoma of the upper aerodigestive tract: a historical perspective with review of their utility and limitations. Part A. Chemically-induced de novo cancer, syngeneic animal models of HNSCC, animal models of transplanted xenogeneic human tumors. Int J Cancer 118(9): 2111-2122.

Smith MR, Saad F, Coleman R, Shore N, Fizazi K, Tombal B, Miller K, Sieber P, Karsh L, Damião R, Tammela TL, Egerdie B, Van Poppel H, Chin J, Morote J, Gómez-Veiga F, Borkowski T, Ye Z, Kupic A, Dansey R, Goessl C (2012) Denosumab and bone-metastasis-free survival in men with castration-resistant prostate cancer: results of a phase 3 , randomised, placebo-controlled trial. Lancet 379(9810): 39-46.

Sun X, Clermont PL, Jiao W, Helgason CD, Gout PW, Wang Y, Qu S (2016) Elevated expression of the centromere protein-A(CENP-A)-encoding gene as a prognostic and predictive biomarker in human cancers. Int $J$ Cancer 139(4): 899-907.

Tannock IF, de Wit R, Berry WR, Horti J, Pluzanska A, Chi KN, Oudard S, Théodore C, James ND, Turesson I, Rosenthal MA, Eisenberger MA, 
Investigators T (2004) Docetaxel plus prednisone or mitoxantrone plus prednisone for advanced prostate cancer. N Engl J Med 351(15): 1502-1512.

Tucci M, Bertaglia V, Vignani F, Buttigliero C, Fiori C, Porpiglia F, Scagliotti GV, Di Maio M (2016) Addition of docetaxel to androgen deprivation therapy for patients with hormone-sensitive metastatic prostate cancer: a systematic review and meta-analysis. Eur Urol 69(4): 563-573.

Valastyan S, Weinberg RA (2011) Tumor metastasis: molecular insights and evolving paradigms. Cell 147(2): 275-292.

Vale CL, Burdett S, Rydzewska LHM, Albiges L, Clarke NW, Fisher D, Fizazi K, Gravis G, James ND, Mason MD, Parmar MKB, Sweeney CJ, Sydes MR, Tombal B, Tierney JF, Group SS (2016) Addition of docetaxel or bisphosphonates to standard of care in men with localised or metastatic, hormone-sensitive prostate cancer: a systematic review and meta-analyses of aggregate data. Lancet Oncol 17(2): 243-256.

Wang IC, Chen YJ, Hughes D, Petrovic V, Major ML, Park HJ, Tan Y, Ackerson T, Costa RH (2005a) Forkhead box M1 regulates the transcriptional network of genes essential for mitotic progression and genes encoding the SCF (Skp2-Cks1) ubiquitin ligase. Mol Cell Biol 25(24): 10875-10894.

Wang Y, Xue H, Cutz JC, Bayani J, Mawji NR, Chen WG, Goetz LJ, Hayward SW, Sadar MD, Gilks CB, Gout PW, Squire JA, Cunha GR, Wang YZ (2005b) An orthotopic metastatic prostate cancer model in SCID mice via grafting of a transplantable human prostate tumor line. Lab Invest 85(11): 1392-1404.

Watahiki A, Wang Y, Morris J, Dennis K, O’Dwyer HM, Gleave M, Gout PW (2011) MicroRNAs associated with metastatic prostate cancer. PLoS One 6(9): e24950.
Watson PA, Arora VK, Sawyers CL (2015) Emerging mechanisms of resistance to androgen receptor inhibitors in prostate cancer. Nat Rev Cancer 15(12): 701-711.

Wirth M, Tammela T, Cicalese V, Gomez Veiga F, Delaere K, Miller K, Tubaro A, Schulze M, Debruyne F, Huland H, Patel A, Lecouvet F, Caris C, Witjes W (2015) Prevention of bone metastases in patients with high-risk nonmetastatic prostate cancer treated with zoledronic acid: efficacy and safety results of the Zometa European Study (ZEUS). Eur Urol 67(3): 482-491.

Zheng Y, Guo J, Zhou J, Lu J, Chen Q, Zhang C, Qing C, Koeffler HP, Tong Y (2015) FoxM1 transactivates PTTG1 and promotes colorectal cancer cell migration and invasion. BMC Med Genomics 8: 49.

Zhou J, Wang C, Wang Z, Dampier W, Wu K, Casimiro MC, Chepelev I, Popov VM, Quong A, Tozeren A, Zhao K, Lisanti MP, Pestell RG (2010) Attenuation of Forkhead signaling by the retinal determination factor DACH1. Proc Natl Acad Sci USA 107(15): 6864-6869.

Zustovich F, Pastorelli D (2016) Therapeutic management of bone metastasis in prostate cancer: an update. Expert Rev Anticancer Ther 16: 1-13.

cc)(1) (2) This work is licensed under the Creative Commons Ay ${ }_{\text {Ba }}$ Attribution-Non-Commercial-Share Alike 4.0 International License. To view a copy of this license, visit http:// creativecommons.org/licenses/by-nc-sa/4.0/

(C) The Author(s) named above 2018

Supplementary Information accompanies this paper on British Journal of Cancer website (http://www.nature.com/bjc) 